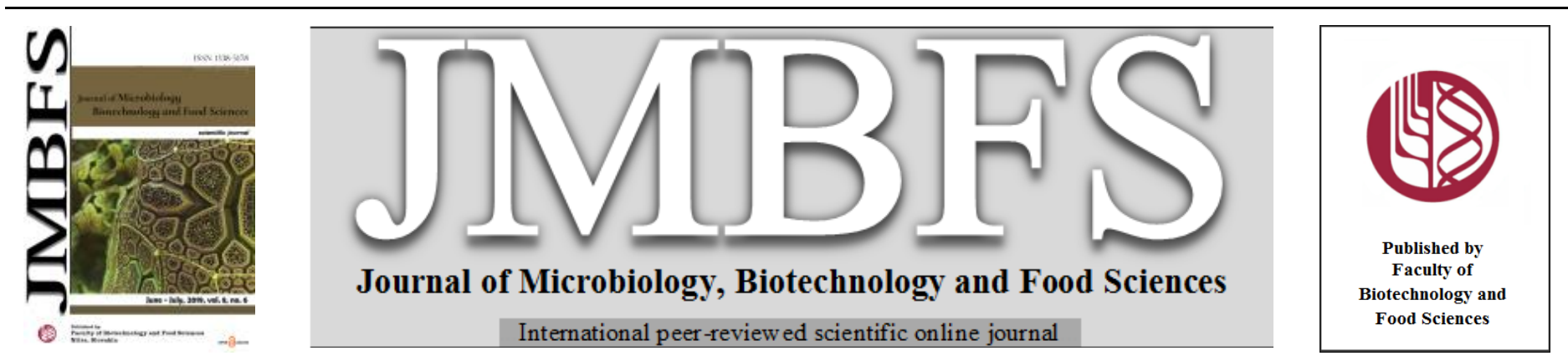

\title{
TEXTURE PROFILE ANALYSIS (TPA) OF ORGANIC SWEETPOTATO (IPOMOEA BATATAS) CULTIVARS AS AFFECTED BY DIFFERENT PROCESSING METHODS
}

\author{
Sochinwechi Nwosisi, Dilip Nandwani and Ramasamy Ravi*
}

Address(es):

Department of Agriculture and Environmental Sciences, College of Agriculture, Human and Natural Sciences, Tennessee State University, Nashville, TN 37209, USA.

*Corresponding author: ramasamyravi@yahoo.com

doi: 10.15414/jmbfs.2019.8.6.1254-1259

\section{ARTICLE INFO}

Received 25. 9. 2018

Revised 22. 1. 2019

Accepted 29. 1. 2019

Published 1. 6. 2019

Regular article OPEN $\bigodot_{\text {ACCESS }}$

\begin{abstract}
Almost one-third of the entire U.S. is buying organic produce. It is believed that organic foods taste better and are more nutritious than conventional foods. To develop successful market positioning, the characteristics desirable to consumers, for sweetpotato must be identified. Different processing methods particularly thermal treatments would impact sweetpotato textures differently and as such affect the consumer liking and eventually product acceptability. Clear understanding of the influence of different thermal treatments on the textural characteristics of sweetpotato is therefore needed. The major objective of this research work was to evaluate the impact of different thermal processing techniques such as baking, pressure cooking, and open cooking on the textural characteristics of sweetpotato cultivars. Six cultivars of sweetpotato grown on a certified organic farm were subjected into different thermal treatments. Baking was done using an air oven for $60 \mathrm{~min}$. Pressure cooking was done using a pressure cooking for $15 \mathrm{~min}$ and open cooking was done using a vessel filled with water $(500 \mathrm{ml})$ for 1 hour. In all thermal treatments, the inside product temperature was kept constant $\left(60 \pm 2^{\circ} \mathrm{C}\right)$. The texture parameters were recorded with a texture analyzer using a $100 \mathrm{~mm}$ dia probe. The samples were also penetrated 5 $\mathrm{mm}$ from the surface using a needle probe of $2 \mathrm{~mm}$ dia. Maximum peak force was set in Newtons. Across the treatments, open cooked Japanese Purple was found to be the hardest although not significantly different from Hernandez open cooked cultivar. Baked Old Yellow sweetpotato was the most gummy and chewy while the softest cultivar was the pressure cooked Old Yellow; however it did not differ significantly from the other five cultivars tested.
\end{abstract}

Keywords: Sweetpotato, cooking, thermal, texture profile

\section{INTRODUCTION}

Sweetpotato is a highly nutritious vegetable and its consumption has been increased in various parts of the world in recent years (Sato, 2016). A USDA survey reported that sweetpotato consumption in the U.S. increased from $1.9 \mathrm{~kg}$ to $3.4 \mathrm{~kg}$ per capita annually between 2000 and 2014 (Johnson et al., 2015) There are several cultivars of sweetpotatoes that vary in their flesh colour, sugar composition and percentage dry matter (La Bonte et al., 2000). Although, traditionally, the fresh produce market prefers orange-fleshed roots (Coolong $\boldsymbol{e} t$ al., 2012) and in the US, orange-fleshed cultivars generally occupy over $90 \%$ of sweetpotato production area (Carpena, 2009). According to the North Carolina Sweetpotato Commission (2015), the more consumer-recognized orange-flesh sweetpotato cultivars are Beauregard, Hernandez, Jewel, Carolina Ruby, Porto Rico, Cordner and Covington. Sweetpotatoes are known to be a good source of energy, protein, fibre, and minerals including potassium, vitamin A, carotenoids and phenolic compounds (Sajeev et al., 2012; Ellong et al., 2014; Laurie et al. 2012; Button, 2015). They are rich in starch, which represents more than $50 \%$ of the carbohydrate components (Ellong et $\boldsymbol{a l}$., 2014). Sweetpotatoes are majorly consumed cooked, baked or fried. Ovens and pressure cookers are currently present in a lot of homes. Sometimes, sweetpotatoes may be pureed or candied to improve shelf life (Padmaja, 2012).

Sweetpotato cultivars react differently when cooked (either a soft or firm texture or colour changes after cooking). Degras (1998) reported that changes may occur in the nutrient and chemical composition of sweetpotatoes while cooking. These changes can alter the starch, dextrins, sugar, carotene and anthocyanin contents (Magness et al., 1971; Messiaen, 1975; Duke, 1983; Susheelamma, 1992) Reddy and Sistrunk (1990) discovered that baking or microwaved cooked sweet potatoes contained high reducing sugars, total sugars and pectins than steamed ones. Martin (1986) reported that the percentage of starch that is converted to maltose in moist sweetpotato cultivars was $63-69 \%$ and about $54 \%$ for dry cultivars. Starch digestion has been said to increase with cooking and cooked sweetpotato starch was more prone to enzymatic breakdown compared to uncooked starch. Bradbury et al. (1985) observed a significant rise in the amount of dietary fibre in boiled and steamed sweetpotatoes possibly due to conversion of part of the starch to resistant starch. In addition, it has been shown that by diluting anthocyanins in cooking water, it could cause a fade colour (Ellong et al., 2014). The white to orange flesh stains more and the cream flesh may change to yellow or greenish or even grey (Ellong $\boldsymbol{e t}$ al., 2014). This change was reportedly caused by the carotenoids degradation (Ellong et al., 2014) Furthermore, enzymatic browning can occur through polyphenol oxidase (PPO) reactions. PPO catalyzes the process of oxidation of mono, di, and poly phenols to o-quinones (Lourenco et al., 1992). It is highly likely that the method of cooking the sweetpotato could alter the dry matter content (Leighton et al., 2010). It has been previously shown that water loss due to evaporation during steaming process can increase the dry matter content of cooked samples (Truong et al., 1997).

Sweetpotato offers great possibility for usage in the food industry for the production of commercial products owing to the fact that sweetpotato is highly rich in starch content (Woolfe, 1992). It becomes imperative to have comprehensive understanding of the functional properties of the different sweetpotato cultivars in order to identify the most appropriate use for food processing (Agnes et al., 2012). Texture (dry matter content) is one of the most crucial parameters directly linked to product quality (Bhattiprolu, 2004) Texture analysis is a measure of food properties relating to how food sample feels in the mouth (Bhattiprolu, 2004). Textural quality can be assessed by use of instruments or by analysis of important constituents (Bach, 2012). According to Truong et al. (1997), parameters provided by an instrument can be good predictors of cooked sweetpotato texture. These parameters include certain characteristics such as mechanical (e.g. mealiness), geometrical (e.g. graininess), compositional (e,g. wateriness) (Szczesniak, 1963), adhesiveness (work required to overcome the force of attraction holding food samples) and chewiness (length of time required to chew a sample) (Bhattiprolu, 2004). Fluctuating levels of firmness that emerge from various cooking treatment could be the motivation to measure the differences among varying cooking methods, for example, 29\% diminishing in hardness for baked samples, $44 \%$ for pressure cooked and $96 \%$ for open cooked specimens when compared with raw samples (Bernad, 2013) Generally, sweetpotato is mostly cooked at home; however, since home preparation is usually lengthy $\left(80-90 \mathrm{~min}\right.$ at $204^{\circ} \mathrm{C}$ for baked sweetpotato), many interested consumers may not use the product due to the length of time required for cooking (Truong and Walter, 1994). Sometimes, it is more reliable to adopt 
instrumental methods for assessing food texture rather than sensory methods. This is because they can be carried out under more controlled conditions. It also offers advantage of saving time and reducing costs, as well as providing more consistent results that are not subjective (Bhattiprolu, 2004)

The major marketable form of sweetpotato is fresh root (Truong and Walter, 1994). The quality of fresh market sweetpotato can vary due to differences in cultivar, conditions of cultivation, and post-harvest handling (Walter, 1987). Several studies have examined the reasons for textural distinction among cultivars and sweetpotato products and to decipher the effect on buyer preference and acceptance (Truong et al., 1997; Tomlins et al., 2004). Sensory characteristics of boiled or baked sweetpotato and preferences of consumers on different types of sweetpotato cultivars have been investigated (Laurie $\boldsymbol{e t}$ al. 2013; Leksrisompong, 2012). Nevertheless, to the best of our knowledge, no study has been done to evaluate instrumentally the effect of different cooking methods on the textural properties of sweetpotato cultivars produced in an organic management system. The main goal of this study was to determine textural differences among six cultivars (Hernandez, Japanese Purple, Murasaki, Orleans, Old Yellow and O'Henry) prepared using open cooking, baking and pressure cooking methods. At the end of this study we will come to know the cultivars with the most desirable texture characteristics that can be grown locally which will be valuable for agricultural producers.

\section{MATERIALS AND METHODS}

\section{Cultivar field production and harvest}

Six sweetpotato cultivars of various flesh and texture attributes were gathered toward the conclusion of the 2016 cultivation season from the Tennessee State University, Nashville TN certified organic farm. Production practices applied were done following the regulations of the National Organic Program. The cultivars include Orleans, Old Yellow, Murasaki, O’Henry and Japanese Purple which have been grown in limited amounts for fresh root markets and processing industry and Hernandez, a moist type sweetpotato and major commercial cultiva well liked in the southern part of the U.S. Sweetpotato slips were purchased in June from Jones Family Farms, Bailey, N.C., Slade Farms, Surrey, V.A., Barefoot farms, TN, USA and planted immediately. It took four months for the slips to mature to vines and the sweetpotato was harvested. After harvest, root curing was done at $13-16{ }^{\circ} \mathrm{C}$ and $80-90 \%$ humid conditions for 5-7 days and set aside for eight weeks before conducting the experiment. Sweetpotato roots were graded according to USDA grading standards. As sweetpotatoes differ in size, only samples that had similar magnitude and shape were chosen for the examination. For each cultivar, three sweetpotato roots were selected randomly, sorted, washed, peeled, and diced into cubes. Roots of average diameter measurement of 1.96 inches, length of 5.06 inches and weight of $5.12 \mathrm{oz}$. were selected for experimental use.

\section{Sweetpotato cooking methods and experimental design}

The open/non-conventional cooking technique, pressure cooking and baking were the three cooking techniques applied in this experiment. Distilled water was utilized as a part of cooking to keep ions from affecting the firm structure of the sweetpotato cultivars.

\section{Open cooking}

Open cooking was performed specifically on high heat with a 2-L stainless steel pot containing $20 \mathrm{oz}$. to $38 \mathrm{oz}$. of bubbling water and they were cooked without peeling their skins (Leighton et al., 2010). No top cover was utilized for pots in the open cooking technique. A fixed time of 20 minutes cooking was employed.

\section{Pressure cooking}

Pressure cooking was done in a 2-L stainless steel pot, with 20-38 ounces of water and they were cooked without peeling their skins (Leighton et al., 2010) Cooking pots were secured with the customary top for pressure cooking. In pressure cooking, the temperature used was $100^{\circ} \mathrm{C}$ and with similar specific time of 20 minutes.

\section{Baking}

Baked samples were heated in aluminum container at $204{ }^{\circ} \mathrm{C}$ for 90 min within an oven. Cooking duration was chosen with the assistance of sensory tests (Leksrisompong et al., 2012).

\section{Instrumental texture profile analysis}

After cooking, all sweetpotato were left to cool at room temperature $\left(30 \pm 2^{\circ} \mathrm{C}\right)$, then peeled, diced into one-inch cube square samples and put away in independently sealed and labeled polythene bags to prevent loss of moisture before completing instrumental examination. Texture Profile Analysis (TPA) was done utilizing a texture analyzer TA HD Plus (Texture Technologies) with a leve plate of $40 \mathrm{~mm}$ in breadth. The samples were packed to $75 \%$ of their unique stature by two continuous compressions. The crosshead speed was set at 1.66 $\mathrm{mm} / \mathrm{sec}$. Configured height was at $50 \mathrm{~mm}$. Pre-test speed was set at $1.00 \mathrm{~mm} / \mathrm{sec}$ while post-test speed was $5.00 \mathrm{~mm} / \mathrm{sec}$. Testing compression was done as follows. The plate approaches the specimen (one each squared sweetpotato cube) from the calibrated height $(50 \mathrm{~mm})$ with the pre-test speed; packed it to half of the original height with test speed; plate goes back to the original position using post-test speed. Once the test is finished, the pulverized example was expelled, and the stage surface was cleaned to evacuate the extracted dampness or water At that point, the next specimen was set underneath the plate. Three samples for each treatment were tested. Care was taken to guarantee the removal of the specimen from the plate when the plate finished the second compression cycle and came back to its original position. The sample was compressed twice in order to mimic the mastication process. Six test parameters resulted from the analysis of a force versus time curve (Figure 1) was obtained during the compression test.

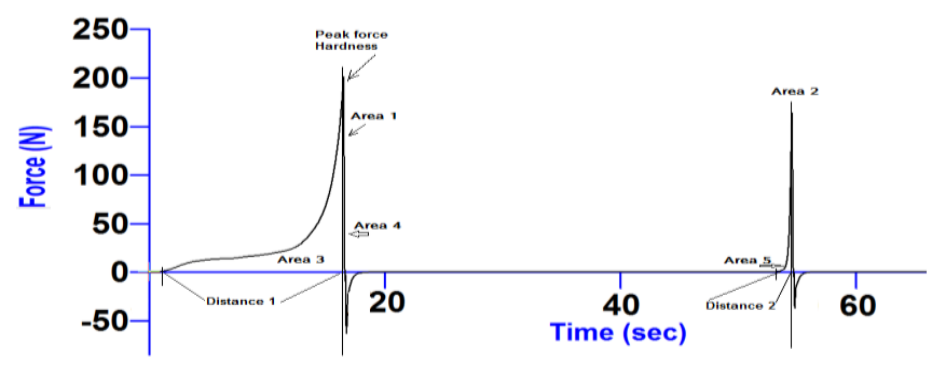

Figure 1 Typical texture (TPA) profile curve showing measurement of texture parameters

As described by Bourne (1978), we assessed the hardness, chewiness, springiness, cohesiveness, gumminess, and resilience. These terms were defined as follows (Szczesniak, 1975): Hardness: force required to cause a deformation Chewiness: time required to chew a food sample to a state suitable for swallowing, Springiness: the rate at which a deformed material goes back to its intact state after deformation, Cohesiveness: extent to which a sample can be deformed before rupturing, Adhesiveness: work necessary to overcome the force of attraction between the food surface and other materials in contact with the food, Gumminess: energy required to breakdown a semi-solid food to a suitable state for swallowing, Resilience: a product of a low degree of hardness and a high degree of cohesiveness.

\section{Data analysis}

Data collection and calculation were accomplished using exponent software of the texture analyzer. Instrumental texture parameters from the force versus time curves were recorded. Three sweetpotatoes per cultivar were analyzed in each treatment. Data from the texture profile analysis were combined for analysis of variance (ANOVA) using PROC GLM in SAS (Ver. 9.4, SAS, Inc., Cary, N.C.) to determine significant influences of primary parameters - cultivar and cooking methods on the secondary parameters (hardness, springiness, cohesiveness, gumminess, chewiness, and resilience). If interactions of cultivar and cooking methods were significant, they were used to explain the results. When the main effect was significant, Fisher's least significant difference (LSD) test was used for multiple comparisons between mean values of the variables (cultivar and cooking methods)

\section{RESULTS AND DISCUSSION}

The ANOVA results indicated that the texture profile parameters were significantly affected by the thermal treatments. Cultivar and cooking method affected the instrumental texture parameters of the sweetpotatoes (Table 1). 
Table 1 ANOVA results ( $F$ values) showing effects of cultivar, cooking methods and their interactions on instrumental texture parameters.

\begin{tabular}{|c|c|c|c|c|}
\hline & Sources & $\begin{array}{l}\text { Degree of } \\
\text { Freedom }\end{array}$ & F-Value & P-Value \\
\hline \multirow[t]{4}{*}{ Hardness } & Model & 17 & 222.31 & $<0.0001$ \\
\hline & Cultivar & 5 & 51.20 & $<0.0001$ \\
\hline & Cooking method & 2 & 284.72 & $<0.0001$ \\
\hline & Cultivar * Cooking method & 10 & 295.39 & $<0.0001$ \\
\hline \multirow[t]{4}{*}{ Springiness } & Model & 17 & 39.46 & $<0.0001$ \\
\hline & Cultivar & 5 & 46.22 & $<0.0001$ \\
\hline & Cooking method & 2 & 31.19 & $<0.0001$ \\
\hline & Cultivar * Cooking method & 10 & 37.74 & $<0.0001$ \\
\hline \multirow[t]{4}{*}{ Cohesiveness } & Model & 17 & 13.98 & $<0.0001$ \\
\hline & Cultivar & 5 & 23.75 & $<0.0001$ \\
\hline & Cooking method & 2 & 28.18 & $<0.0001$ \\
\hline & Cultivar * Cooking method & 10 & 6.25 & $<0.0001$ \\
\hline \multirow[t]{4}{*}{ Gumminess } & Model & 17 & 77.88 & $<0.0001$ \\
\hline & Cultivar & 5 & 26.67 & $<0.0001$ \\
\hline & Cooking method & 2 & 62.68 & $<0.0001$ \\
\hline & Cultivar * Cooking method & 10 & 106.52 & $<0.0001$ \\
\hline \multirow[t]{4}{*}{ Chewiness } & Model & 17 & 68.05 & $<0.0001$ \\
\hline & Cultivar & 5 & 34.07 & $<0.0001$ \\
\hline & Cooking method & 2 & 58.50 & $<0.0001$ \\
\hline & Cultivar * Cooking method & 10 & 86.96 & $<0.0001$ \\
\hline \multirow[t]{4}{*}{ Resilience } & Model & 17 & 24.35 & $<0.0001$ \\
\hline & Cultivar & 5 & 16.00 & $<0.0001$ \\
\hline & Cooking method & 2 & 85.06 & $<0.0001$ \\
\hline & Cultivar * Cooking method & 10 & 16.38 & $<0.0001$ \\
\hline
\end{tabular}

\section{Effect of Cultivars on textural characteristics of sweetpotato}

Old Yellow differed from other cultivars, having the highest values for cohesion, gumminess and chewiness (Table 2). In the chewing process, the cell wall experiences twisting or breaking based on the characteristics of the cell wall (Waldron et al., 1997). As for springiness, Old Yellow also held the highest value and did not present significant difference with the Japanese Purple cultivar. Hernandez held the highest value for hardness although it did not differ significantly from Japanese Purple (Table 2). Dry matter content has been reported to be connected to some degree with the texture of potatoes, although this reality is not really clear (Van Marle $\boldsymbol{e t}$ al., 1997). According to Truong $\boldsymbol{e t}$ al. (2011), such sweetpotato cultivars with high dry matter content have firm and mealy texture after cooking while those with low dry matter content have soggy texture after cooking. As for resilience, Hernandez also held the highest value, however, it did not vary significantly from Japanese Purple and Old yellow cultivars (Table 2). O'Henry produced the lowest values for gumminess and hardness. O' Henry also produced the lowest values for chewiness and resilience, however, it was not significantly different from Murasaki and Orleans. Walter et al. (1997) reported that the product processed from soft-sweet type sweetpotato was softer, moister, had fewer particles, more mass cohesion, was easier to swallow, and had an oily mouthfeel. Orleans produced the lowest parameters for springiness and cohesiveness, however, it did not vary significantly from Murasaki (and O' Henry in the case of cohesiveness) (Table 2).

Table 2 Sweetpotato cultivars and their instrumental texture parameters

\begin{tabular}{rcccccr}
\hline & \multicolumn{7}{c}{ Cultivars } \\
Parameters & Hernandez & Japanese Purple & Murasaki & Orleans & Old Yellow & O'Henry \\
\cline { 2 - 6 } Texture & $2.47 \mathrm{dc}$ & $2.43 \mathrm{~d}$ & $2.62 \mathrm{bcd}$ & $2.66 \mathrm{bcd}$ & $263 \mathrm{bcd}$ & $2.61 \mathrm{bcd}$ \\
\cline { 2 - 7 } Rank & 5 & 6 & 3 & 1 & 2 & 4 \\
\hline Hardness (N) & $231.50 \mathrm{a}$ & $221.76 \mathrm{ab}$ & $197.56 \mathrm{bc}$ & $197.71 \mathrm{bc}$ & $182.02 \mathrm{c}$ & $89.39 \mathrm{~d}$ \\
\cline { 2 - 7 } Rank & 1 & 2 & 4 & 3 & 5 & 6 \\
\hline Springiness & $0.64 \mathrm{c}$ & $0.73 \mathrm{ab}$ & $0.55 \mathrm{~d}$ & $0.53 \mathrm{~d}$ & $0.75 \mathrm{a}$ & $0.69 \mathrm{bc}$ \\
\cline { 2 - 7 } Rank & 4 & 2 & 5 & 6 & 1 & 3 \\
\hline Cohesiveness & $0.10 \mathrm{bc}$ & $0.10 \mathrm{~b}$ & $0.08 \mathrm{bcd}$ & $0.07 \mathrm{~d}$ & $0.13 \mathrm{a}$ & $0.08 \mathrm{~cd}$ \\
\hline Rank & 2 & 2 & 3 & 4 & 1 & 3 \\
\hline Gumminess & $19.30 \mathrm{~b}$ & $17.83 \mathrm{~b}$ & $16.95 \mathrm{~b}$ & $15.07 \mathrm{~b}$ & $28.54 \mathrm{a}$ & $7.97 \mathrm{c}$ \\
Rank & 2 & 3 & 4 & 5 & 1 & 6 \\
\hline Chewiness & $12.58 \mathrm{~b}$ & $12.33 \mathrm{~b}$ & $10.40 \mathrm{bc}$ & $9.28 \mathrm{bc}$ & $26.54 \mathrm{a}$ & $5.30 \mathrm{c}$ \\
\cline { 2 - 6 } Rank & 2 & 3 & 4 & 5 & 1 & 6 \\
\hline Resilience & $0.44 \mathrm{a}$ & $0.33 \mathrm{a}$ & $0.04 \mathrm{~b}$ & $0.07 \mathrm{~b}$ & $0.32 \mathrm{a}$ & $0.03 \mathrm{~b}$ \\
Rank & 1 & 2 & 5 & 4 & 3 & 6 \\
\hline
\end{tabular}

${ }^{*}$ Mean values in a row with different letters differ significantly at $\mathrm{P}<0.05$ by LSD. Ranking by high to low values among the cultivars.

Texture, or mouth-feel, is a major attribute in deciding overall consumer acceptance of sweetpotato cultivars. A mixture of sensory attributes of the sweetpotato root can impact consumer taste and overall acceptability. According to a sensory study by Nwosisi $\boldsymbol{e t}$ al. (2017) using a semi-trained sensory panel, the least favored cultivars (Japanese Purple) had watery [due to a somewhat lesser dry matter/ moisture content of the white fleshed sweetpotato as reported by Leighton $\boldsymbol{e t}$ al. (2010)], sweet, fibrous, vanilla, and dense textural traits. Among other things, the lower acceptance of hardness or dense textural traits can be confirmed from our TPA results. Japanese Purple and Hernandez with the least liked textural traits from their study also showed the greatest hardness and resilience. However, they did not differ significantly from each other and from some of the other cultivars (Put those cultivars in this bracket). Walter $\boldsymbol{e t}$ al. (2002) discovered that sensory hardness and density were highly correlated with the value of instrumental measurements while cohesiveness, oiliness and moistness were negatively correlated with the value of instrumental measurements. In an experiment conducted on sweetpotato French fries, consumers preferred the caramel flavor and disliked starch flavor, and first-bite moistness and cohesiveness of mass in texture. On the other hand, there have been other reports that the most essential sensory descriptors affecting consumer acceptability were starch and stickiness as they were more favored by consumers compared to the least preferred types which were neither starchy nor sticky (Tomlins et al., 2004; Nwosisi et al., 2017). Following the use of instruments, a fully-trained sensory panel should thus be set up to confirm the results of our present study as the process of determining the acceptance of a food product is measured from different dimensions (Costell et al., 2010).

Effect of cooking methods on textural characteristics of sweetpotatoes

Springiness, cohesiveness, gumminess and chewiness were highest in the baked treatments (Table 3). While hardness and resilience were observed to be highest 
in the open cooked treatments, cohesiveness was found to be greatest in the pressure-cooked treatments although it was not significantly different from the baked treatment. Hardness, gumminess, chewiness and resilience were significantly reduced in pressure-cooked sweetpotatoes when compared to the rest of the cooking methods. Springiness was least among the open-cooked treated sweetpotato cultivars.

Table 3 Effect of cooking methods on textural properties of sweetpotato cultivars

\begin{tabular}{ccccccc}
\hline & \multicolumn{7}{c}{ Cooking methods } \\
\cline { 2 - 7 } & Baking & Rank & Open cooking & Rank & Pressure cooking & Rank \\
\hline Hardness (N) & $188.11 \mathrm{~b}$ & $(2)$ & $270.84 \mathrm{a}$ & $(1)$ & $101.02 \mathrm{c}$ & $(3)$ \\
\hline Springiness (\%) & $0.70 \mathrm{a}$ & $(1)$ & $0.60 \mathrm{c}$ & $(3)$ & $0.65 \mathrm{~b}$ & $(2)$ \\
\hline Cohesiveness (\%) & $0.10 \mathrm{a}$ & $(2)$ & $0.07 \mathrm{~b}$ & $(3)$ & $0.11 \mathrm{a}$ & $(1)$ \\
\hline Gumminess & $23.86 \mathrm{a}$ & $(1)$ & $19.27 \mathrm{~b}$ & $(2)$ & $9.70 \mathrm{c}$ & $(3)$ \\
\hline Chewiness & $19.80 \mathrm{a}$ & $(1)$ & $12.02 \mathrm{~b}$ & $(2)$ & $6.40 \mathrm{c}$ & $(3)$ \\
\hline Resilience (\%) & $0.05 \mathrm{~b}$ & $(3)$ & $0.54 \mathrm{a}$ & $(1)$ & $0.20 \mathrm{~b}$ & $(2)$ \\
\hline
\end{tabular}

Mean values in a row with different letters indicate significantly different at $\mathrm{P}<0.05$. Values in parenthesis in a row indicate the ranking among the cooking methods with respect to that parameter.

Different methods of cooking are impacted by a blend of various factors, like temperature and time, thus when comparing various cooking techniques, care should be taken as outcomes will fluctuate due to the type of cooking treatment applied and the food product being prepared (Bernad, 2013). The deciding factor for the texture of plant substances are the cell wall's properties, magnitude and spread of vesicles within the cell's cytoplasm and the air-spaces located inbetween cells (Bach, 2012). In addition, other components such as size and magnitude of food particles, level of heterogeneity, and the association of starch with lipids, protein and fiber would modify the characteristics that arise due to the thermal treatment (Trancoso-Reyes et al., 2016). As water flows down during osmosis into the cell vacuole to fill the cell wall compartment, turgor pressure helps to keep the cells rigid (Bach, 2012). Flaccidity sets in when turgor pressure is lost (Bach, 2012). Cells with high turgor pressure are usually stiff and hard, whereas flaccid cells are rubber-like (Bach, 2012). The sweetpotato flesh is composed mainly of starch, which only swells up by water absorption and then breaks down due to the hydrolysis of the weak bonds (Sugri et al., 2012). Starch granules in the raw state on the other hand are hard, tightly packed, tiny aggregation of starch molecules, which give a chalky feels when chewed out of the cells (Leighton et al., 2010). During cooking of the sweetpotao, the starch granules begin to soften at about $66{ }^{\circ} \mathrm{C}$ (this temperature varies in plants), and moisture is absorbed, which impairs their compact structure and the granules swell up to many times their original size and weight (McGee, 2004).

\section{Comparison of the effect of thermal treatments on sweetpotato cultivars}

Of all the treatments tested, baked Old Yellow cultivars were the most gummy and chewy (Table 4). Baked Old Yellow sweetpotato was also the springiest, however it di did not vary significantly from baked Japanese Purple sweetpotato cultivar. The maximum viscosity attained during the heating cycle, peak viscosity, shows the swelling ability of the starch granules before they are physically broken down (Ikegwu and Okechukwu, 2010). Truong and Walter
(1994) observed in their study that although in baked roots, the microstructure of the cell wall was destroyed completely, many gelatinized starch granules still retained integrity and shape. This finding contradicts with what was reported on Egyptian sweetpotato cultivar (Damir, 1989). There was a complete shape deformation of starch granules baked at $175{ }^{\circ} \mathrm{C}$ for $60 \mathrm{~min}$. The extent of deformation of starch granules and other contents associated with the structure of baked sweetpotato likely varies among cultivars and may contribute to textural variability (Truong and Walter, 1994). The proportion of amylopectin and amylose in starch may thus account for the texture attributes in food products, including, stickiness, and resistance against shear stress, swelling of starch granules due to heat, solubility, tackiness, stability of gel, cold swelling, and retrogradation. Japanese Purple cultivar prepared using the open cooking method was the hardest, however, they were not different from open-cooked Hernandez sweetpotato cultivar (Table 4). TPA hardness and fracturability showed comparative patterns and were highly correlated with peak force (Truong $\boldsymbol{e t}$ al., 1998). It is noteworthy that the strength of the cell wall and cell tugor pressure are the reason for hardness in plant tissue. When heat is applied however, the cell membrane structure is disturbed, and there is loss of turgor pressure wherein water filters from the cells (Bach, 2012). First, the cell tissues loose solidness quickly, a turgor pressure diminishes then the cell wall loses its integrity as a result of a loss of pectic compounds. The open-cooked Hernandez cultivars were also the most resilient, however, they did not vary significantly from the Japanese purple and Old Yellow sweetpotato also prepared using open cooking method (Table 4). Baked Old Yellow sweetpotato were also the most cohesive of al treatments and cultivars tested, however, their cohesive property was not significantly different from Japanese Purple and Old Yellow pressure-cooked sweetpotato, Old Yellow open-cooked sweetpotato and Hernandez baked Sweetpotato. Boiling at high temperatures disturbs cell cohesion and adhesion, bringing about a defect in tissue rigidity (Truong et al., 1998). Asides from this, potatoes with greater dry matter content are softer in texture after they are boiled (Thybo and Martens, 2000).

Table 4 Texture parameters of sweetpotato cultivars as affected by different cooking methods

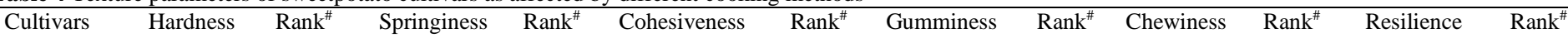
(N) (\%)

$(\%)$

\begin{tabular}{|c|c|c|c|c|c|c|c|c|c|c|c|c|c|}
\hline \multirow{6}{*}{$\begin{array}{l}\text {.0 } \\
\text {.0 } \\
0 \\
0 \\
0 \\
0\end{array}$} & Hernandez & $532.81 \mathrm{ab}$ & 2 & $0.68 \mathrm{bc}$ & 7 & 0.07 cdef & 14 & $39.47 \mathrm{~b}$ & 3 & $26.91 \mathrm{~b}$ & 3 & $1.26 \mathrm{a}$ & 1 \\
\hline & $\begin{array}{c}\text { Japanese } \\
\text { Purple }\end{array}$ & $562.47 \mathrm{a}$ & 1 & $0.68 \mathrm{bc}$ & 8 & 0.07 cdef & 12 & $42.35 \mathrm{~b}$ & 2 & $28.68 \mathrm{~b}$ & 2 & $0.93 \mathrm{a}$ & 2 \\
\hline & Murasaki & $252.32 \mathrm{~d}$ & 6 & $0.39 \mathrm{~h}$ & 18 & $0.06 \mathrm{def}$ & 16 & $16.10 \mathrm{c}$ & 6 & $6.18 \mathrm{c}$ & 8 & $0.20 \mathrm{~b}$ & 12 \\
\hline & Orleans & $171.19 \mathrm{e}$ & 7 & $0.49 \mathrm{fgh}$ & 16 & $0.05 \mathrm{f}$ & 18 & $8.33 \mathrm{~cd}$ & 9 & $4.06 \mathrm{c}$ & 11 & $0.16 \mathrm{~b}$ & 4 \\
\hline & Old Yellow & $49.64 \mathrm{gh}$ & 14 & 0.63 bcde & 11 & $0.12 \mathrm{ab}$ & 4 & $5.86 \mathrm{~cd}$ & 12 & $3.73 \mathrm{c}$ & 14 & $0.88 \mathrm{a}$ & 3 \\
\hline & O’Henry & $56.64 \mathrm{gh}$ & 13 & $0.73 \mathrm{~b}$ & 3 & $0.06 \mathrm{ef}$ & 17 & $3.52 \mathrm{~d}$ & 15 & $2.58 \mathrm{c}$ & 15 & $0.02 \mathrm{~b}$ & 11 \\
\hline \multirow{6}{*}{ 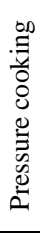 } & Hernandez & $58.67 \mathrm{gh}$ & 12 & $0.71 \mathrm{bc}$ & 6 & $0.10 \mathrm{bcd}$ & 6 & $6.36 \mathrm{~cd}$ & 10 & $4.47 \mathrm{c}$ & 10 & $0.02 \mathrm{~b}$ & 14 \\
\hline & $\begin{array}{c}\text { Japanese } \\
\text { Purple }\end{array}$ & $40.03 \mathrm{gh}$ & 16 & $0.58 \mathrm{cdef}$ & 13 & $0.15 \mathrm{a}$ & 2 & $6.25 \mathrm{~cd}$ & 11 & $3.75 \mathrm{c}$ & 13 & $0.02 \mathrm{~b}$ & 13 \\
\hline & Murasaki & $33.69 \mathrm{~h}$ & 17 & 0.54 defg & 14 & 0.10 bcde & 9 & $3.42 \mathrm{~d}$ & 17 & $1.85 \mathrm{c}$ & 17 & $0.01 \mathrm{~b}$ & 16 \\
\hline & Orleans & $372.75 \mathrm{c}$ & 4 & $0.66 \mathrm{bcd}$ & 10 & $0.09 \mathrm{bcdef}$ & 10 & $33.38 \mathrm{~b}$ & 4 & $22.20 \mathrm{~b}$ & 5 & $0.03 \mathrm{~b}$ & 10 \\
\hline & Old Yellow & $25.77 \mathrm{~h}$ & 18 & $0.67 \mathrm{bc}$ & 9 & $0.13 \mathrm{ab}$ & 3 & $3.34 \mathrm{~d}$ & 18 & $2.23 \mathrm{c}$ & 16 & $0.01 \mathrm{~b}$ & 15 \\
\hline & O'Henry & $75.22 \mathrm{fgh}$ & 10 & $0.72 \mathrm{~b}$ & 4 & $0.07 \mathrm{cdef}$ & 13 & $5.43 \mathrm{~cd}$ & 13 & $3.92 \mathrm{c}$ & 12 & $0.01 \mathrm{~b}$ & 18 \\
\hline \multirow{6}{*}{ 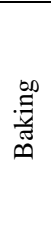 } & Hernandez & $103.03 \mathrm{fg}$ & 9 & $0.53 \mathrm{efg}$ & 15 & $0.12 a b c$ & 5 & $12.08 \mathrm{~cd}$ & 8 & $6.37 \mathrm{c}$ & 7 & $0.05 \mathrm{~b}$ & 8 \\
\hline & $\begin{array}{c}\text { Japanese } \\
\text { Purple } \\
\end{array}$ & $62.80 \mathrm{gh}$ & 11 & $0.94 \mathrm{a}$ & 2 & $0.07 \mathrm{cdef}$ & 11 & $4.89 \mathrm{~cd}$ & 14 & $4.58 \mathrm{c}$ & 9 & $0.04 \mathrm{~b}$ & 9 \\
\hline & Murasaki & $306.67 \mathrm{~d}$ & 5 & $0.72 \mathrm{~b}$ & 5 & $0.10 \mathrm{bcd}$ & 8 & $31.34 \mathrm{~b}$ & 5 & $23.16 \mathrm{~b}$ & 4 & $0.09 \mathrm{~b}$ & 5 \\
\hline & Orleans & $49.20 \mathrm{gh}$ & 15 & $0.45 \mathrm{gh}$ & 17 & $0.07 \mathrm{def}$ & 15 & $3.49 \mathrm{~d}$ & 16 & $1.60 \mathrm{c}$ & 18 & $0.01 \mathrm{~b}$ & 17 \\
\hline & Old Yellow & $470.67 \mathrm{~b}$ & 3 & $0.95 \mathrm{a}$ & 1 & $0.16 \mathrm{a}$ & 1 & $76.41 \mathrm{a}$ & 1 & $73.67 \mathrm{a}$ & 1 & $0.08 \mathrm{~b}$ & 6 \\
\hline & O’Henry & $136.30 \mathrm{ef}$ & 8 & 0.62 bcde & 12 & $0.10 \mathrm{bcd}$ & 7 & $14.96 \mathrm{~cd}$ & 2 & $9.41 \mathrm{c}$ & 6 & $0.07 \mathrm{~b}$ & 7 \\
\hline
\end{tabular}

${ }^{*}$ Values followed by different letters differ significantly at $\mathrm{p}<0.05$ by LSD. "Ranking based on the values from high to low.

The softest sweetpotato were the Old Yellow cultivar type prepared using the pressure cooking method, it however did not vary significantly from many of the other cultivars (Orleans, Murasaki, O'Henry, Japanese and Hernandez) across the various treatments tested (Table 4). An investigation by Truong et al. (1998) 
revealed that sweetpotato samples immersed in boiling water were softer than the raw sweetpotato as shown by a less steep bend with reduced fracture strength. In a different report by Leighton et al. (2010), decrease in both shear strain and stress was seen in every single cultivar prepared with steaming technique in contrast to the qualities observed for raw sweetpotato. The possible reason could be because of the extent in which starch and cell wall constituents break down during cooking, which then impacts various textural properties among sweetpotato cultivars (Leighton et al., 2010). The least springy sweetpotato was the open-cooked Murasaki cultivar, however its low springiness value was not significantly different from that observed for the open-cooked and baked Orleans sweetpotato (Table 4). The least cohesive, gummy, chewy and resilient cultivars were observed to be the open-cooked Orleans, pressure-cooked Old Yellow, baked Orleans and pressure-cooked O'Henry cultivars, respectively. Leighton $\boldsymbol{e}$ al. (2010) also reported that during boiling, take-up or adsorption of water lessens the cohesiveness and weakens the cell walls. Other than this, pectic polymers that play a part in cell adherence are broken down by $\beta$-elimination at higher temperatures, and divalent cations, particularly $\mathrm{Ca}^{2+}$ and $\mathrm{Mg}^{2+}$ can decrease softening during heating, as the particles cross-interface the pectic polysaccharides associated with the cell adhesion Leighton et al. (2010). The conduct of the above parameters is related to the sample properties and composition and essentially to the concentration of starch (Trancoso-Reyes $\boldsymbol{e t}$ al., 2016). On heating, the crystalline areas are disturbed, water is taken up and the starch forms a gel. The gelatinised starch in the case of potatoes can at times occupy the whole cell, in which case the potato will be viewed as soft.

\section{Correlations among TPA parameters}

The correlation coefficients exhibited a positive relationship between the texture variables (springiness, gumminess, chewiness, resilience and hardness) of the sweetpotato roots (Table 5). Gumminess was significantly correlated with hardness and chewiness, suggesting they have a relationship. Chewiness was significantly correlated with hardness. In support of our results, experimental data examination by Walter et al. (2002) to determine the textural measurements and product quality of restructured sweetpotato French fries, indicated that hardness decreases with calcium concentrations and gel strength. Also, gumminess also appeared to be affected similarly as hardness, but the coefficient of variation was large to make this relationship uncertain (Walter et al., 2002).

Table 5 Correlation coefficients of TPA parameters

\begin{tabular}{lcccccc}
\hline \multicolumn{1}{l}{ Correlation coefficients } & & & & & & \\
\hline TPA parameters & Springiness & Cohesiveness & Gumminess & Chewiness & Resilience & Hardness \\
\hline Springiness & $1.00-$ & & & & & \\
\hline Cohesiveness & 0.27 & & & & & \\
\hline Gumminess & 0.43 & 0.26 & & & \\
\hline Chewiness & 0.53 & 0.34 & $0.98^{*}$ & & \\
\hline Resilience & 0.03 & -0.08 & 0.31 & 0.22 & & \\
\hline Hardness & 0.23 & -0.07 & $0.88^{*}$ & $0.78^{*}$ & 0.53 & $1.00-$ \\
\hline
\end{tabular}

* Values in asterisks are significant at $\mathrm{p}<0.05$ by LSD

\section{CONCLUSION}

The texture profile analysis (TPA) was employed to predict the consumer acceptability of organic sweetpotato as affected by different processing methods The mouthfeel characteristics (hardness, springiness, cohesiveness, gumminess and chewiness) can be predicted by using instruments such as texture analyzer. Chewiness was significantly correlated with hardness. Gumminess was significantly correlated with hardness and chewiness suggesting they have a relationship. Hernandez was found to be the hardest cultivar although not significantly different from Japanese Purple. Old Yellow was the most cohesive, gummy and chewy sweetpotato. The least resilient cultivar, O'Henry, was also the least hard, gummy and chewy cultivar, its chewiness and resilience was however not significantly different from Muraski and Orleans. The springies cultivar was Old Yellow, though it did not differ significantly from the Japanese Purple cultivar. Hernandez was the most resilient cultivar, however it was not significantly different from Murasaki and Orleans. The different processing conditions such as open cooking, pressure cooking and baking affect the textura parameters differently depending upon the conditions. Springiness, gumminess and chewiness were highest under baking conditions. Hardness and resilience were greatest in open-cooked treatments. Cohesiveness was found to be greatest in the pressure-cooked treatments, although it was not significantly different from the baked treatment. In pressure-cooked sweetpotato however, hardness, gumminess, chewiness and resilience were found to be reduced significantly when compared to the rest of the cooking methods. Springiness had the lowest values among the open-cooked treated sweetpotato cultivars. Across the treatments, open-cooked Japanese Purple was found to be the hardest, although not significantly different from Hernandez open-cooked cultivar. Baked Old Yellow sweetpotato was the most gummy and chewy while the softest cultivar was the pressure-cooked Old Yellow; however it did not differ significantly from many of the other cultivars (Orleans, Murasaki, O'Henry, Japanese and Hernandez) tested. Results of this study indicate that the prediction of mouthfeel characteristics using instruments will reduce the time and energy to conduct sensory evaluations and helps to assess sweetpotato sensory quality, thus setting bench marks for marketability. Although, texture stand out amongst the mos essential sensory traits of root crops, it has been described as one of the most difficult attributes to gauge instrumentally. Studying the changes in texture properties of different sweetpotato cultivars prepared under different cooking methods and time would help us improve the sensory properties of each meal we consume as we would be able to determine the desirable changes in the major textural characteristics and the optimum time needed for preparation thereby reducing the time spent cooking. Although, qualitative descriptive analysis is a time-consuming process, however, when applied to promising cultivars, it can provide vital information that can predict potential preference by consumers.

\section{REFERENCES}

AGNES, N., AGNES, N., YUSUF, B., JUDITH, N., TRUDE, W. 2012. Potential use of selected sweetpotato (Ipomea batatas L.) cultivars as defined by chemical and flour pasting characteristics. Food and Nutrition Sciences, 3, 889-896. https://doi.org/10.4236/fns.2012.37118

BACH, V. 2012. Sensory quality and chemical composition of culinary preparations of root crops. Aarhus University, Department of Food Science. Denmark. Doctoral dissertation, 1-76.

BERNAD, M. D. 2013. Comparison of vacuum treatments and traditional cooking in vegetables using instrumental and sensory analysis (Doctora dissertation). Universitat Politècnica de València, Valencia, 1-200. DOI: 10.1007/s12161-013-9638-0

BHATTIPROLU, S. 2004. Color, texture and rehydration characteristics of ohmically treated Sweetpotato. Faculty of the Louisiana State University and Agricultural and Mechanical College. Doctoral dissertation, 1-35.

BOURNE, M. C. 1978. Texture profile analysis. Food Technol, 32, 62-72.

https://doi.org/10.1111/j.1745-4603.1978.tb01219.x.

BRADBURY, J. H., BEATTY, R.E., BRADSHAW, K., HAMMER, B.,

HOLLOWAY, W.D., JEALOUS, W., LAU, J., NGUYEN, T., SINGH, U. 1985.

Chemistry and nutritive value of tropical root crops in the South Pacific.

Proceeding of the Nutrition Society of Australia, 10, 185-188.

BUTTON, K. 2015. Processing sweetpotato into French fries. Kansas State University, Manhattan, KS. Master's Thesis, 1- 45.

CARPENA, A. L. 2009. Important cultivars, varieties, and hybrids. In Loebenstein, G and Thottappilly, G. (eds). The sweetpotato. Springer science Business Media BV, Houten, The Netherlands, 27-40.

COOLONG, T. K., SEEBOLD, R., BESSIN, T., WOODS, FANNIN, S. 2012 Sweetpotato production for Kentucky, ID-195. Cooperative Extension Service, University Kentucky College of Agriculture, Lexington, KY.

COSTELL, E., TARREGA, A., BAYARRI, S. 2010. Food Acceptance: The Role of Consumer Perception and Attitudes. Chemosensory Perception, 3, 42-50. http://dx.doi.org/10.1007/s12078-009-9057-1

DAMIR, A. A. 1989. Effect of heat penetration during cooking on some physicochemical properties and microstructure of sweetpotato. Food Chem., 34, 41-55. https://doi.org/10.1016/0308-8146(89)90032-0

DEGRAS, L. 1999. Le Technicien d'Agriculture Tropicale, La Patate Douce. Maisonneuve et Larose, Paris.

DUKE, J. A. 1983. Handbook of Energy Crops http://www.hort.purdue.edu/newcrop/duke_energy/Ipomoea_batatas.html

ELLONG, E. N., BILLARD, C., ADENET, S. 2014. Comparison of physicochemical, organoleptic and nutritional abilities of eight sweetpotato (Ipomoea batatas) cultivars. Food and Nutrition Sciences, 5(02), 196-199. https://doi.org/10.4236/fns.2014.52025

IKEGWU, O. J., OKECHUKWU, P. E. 2010. Physicochemical and Pasting Characteristics of Flours and Starch from Achi Brachystegia eurtcoma Seed. $\begin{array}{llrr}\text { Journal of Food } & \text { T(2), 58-66. }\end{array}$ https://doi.org/10.3923/jftech.2010.58.66

JOHNSON, T., WILSON, N., WOROSZ, M. R., FIELDS, D., BOND, J. K 2015. Commodity Highlight: Sweet Potatoes. Economic Research Service: Situation and Outlook, United States Department of Agriculture (USDA), Washington D.C. 
LA BONTE, D. R., PICHA, D. H, JOHNSON, H. A. 2000. Carbohydrate-related changes in sweetpotato storage roots during development. J Am Soc Hortic Sci, $125,200-204$

LAURIE, S. M., VAN JAARSVELD, P. J. FABER, M. PHILPOTT, M. F., LABUSCHAGNE, M. T. 2012. Trans- $\beta$-Carotene, Selected Mineral Content and Potential Nutritional Contribution of 12 sweetpotato Cultivars. Journal of Food Composition and Analysis, 27(2),

$151-159$

https://doi.org/10.1016/j.jfca.2012.05.005

LAURIE, S. M., FABER, M., CALITZ, F. J., MOELICH, E. I., MULLER, N., LABUSCHAGNE, M. T. 2013. The use of sensory attributes, sugar content, instrumental data and consumer acceptability in selection of sweetpotato cultivars. Journal of the Science of Food and Agriculture, 93(7), 1610-1619. https://doi.org/10.1002/jsfa.5932

LEIGHTON, C. S., SCHÖNFELDT, H. C., KRUGER, R. 2010. Qualitative descriptive sensory analysis of five different cultivars of sweet potato to determine sensory and textural profiles. Journal of Sensory Studies, 25(1), 2-18. https://doi.org/10.1111/j.1745-459X.2008.00188.x

LEKSRISOMPONG, P., WHITSON, M., TRUONG, V., DRAKE, M. 2012 Sensory attributes and consumer acceptance of sweetpotato cultivars with varying flesh colors. Journal of Sensory Studies, 27, 59-69. https://doi.org/10.1111/j.1745-459X.2011.00367.x

LOURENCO, E., NEVES, V., MARAIZA, A. 1992. Polyphenol oxidase form sweetpotato: Purification and properties. J Agric Food Chem, 40, 2369-2373. https://doi.org/10.1021/jf00024a009

MAGNESS, J. R., MARKLE, G. M., COMPTON, C. C. 1971. Food and Feed Crops of the United States," Interregional Research Project IR-4. http://www.hort.purdue.edu/newcrop/Crops/Sweetpotato.Html

MARTIN, F. W. 1986. Sugars in staple type sweetpotato as affected by cooking and storage. Journal of the Agricultural University of Puerto Rico, 70 (2), 121

MCGEE, H. 2004. On Food and Cooking: The Science and Lore of the Kitchen. New York, New York: Scribner. ISBN 978-0-684-80001-1.

MESSIAEN, C. M. 1975. "Le Potager Tropical," 3rd Edition, Presses Universitaires de France, Paris, pp. 422-433.

NWOSISI, S., NANDWANI, D., HUI, D., RAVI, R. 2017. Sensory Evaluation of Organic Sweetpotato Cultivars. International Journal of Vegetable Science, 23(6), 536-551. https://doi.org/10.1080/19315260.2017.1346029

NORTH CAROLINA SWEETPOTATO COMMISSION. 2015. Sweetpotato 101. Available from: http://www.ncSweetpotato.com/sweet-potatoes101/difference-between-yam-andsweet-potato/. Accessed March 22, 2015.

PADMAJA, G., SHERIFF, J. T., SAJEEV, M. S. 2012. Food Uses and Nutritional Benefits of Sweetpotato. Fruit, Vegetable and Cereal Science and Biotechnology, 6(1), 115-123.

REDDY, N. N., SISTRUNK, W. A. 1980. Effect of cultivar, size, storage and cooking method on carbohydrates and some nutrients of sweetpotato. Journal of Food Science, 45(3), 682-684. https://doi.org/10.1111/j.13652621.1980.tb04131.x

SAJEEV, M. S., SREEKUMAR, J., VIMALA, B., MOORTHY, S. N., JYOTHI, A. N. 2012. Textural and gelatinization characteristics of white, cream, and orange fleshed sweetpotato tubers (Ipomoea Batatas L.). International journal of food properties, 15(4), 912-931. https://doi.org/10.1080/10942912.2010.509895 SATO, A., 2016. Chemical Constituents of Sweetpotato Genotypes in Relation to Textural Characteristics of Sweetpotato French Fries. (Master's thesis), North Carolina State University, NC. 145Pp.

SUGRI, I., NUTSUGAH, S. K., WIREDU, A. N., JOHNSON, P. N. T. ADUGUBA, D. 2012. Kendall's Concordance Analysis of Sensory Descriptors Influencing Consumer Preference for Sweetpotato in Ghana. American Journal of Food Technology, 7(3), 142-150. https://doi.org/10.3923/ajft.2012.142.150

SUSHELAMMA, N. S., REDDY, G. C., RUKMANI, C. S., THARANATHAN, R. N. 1995. Studies on Sweetpotato. Part I: Changes in the Carbohydrates during $\begin{array}{lll}\text { Processing, } & \text { Starch/Stärke, } & \text { 44(5), }\end{array}$ https://doi.org/10.1002/star.19920440502

SZCZESNIAK, A. S. 1963. Classification of textural characteristics. Journal of Food Science, 28, 385-389. https://doi.org/10.1111/j.1365-2621.1963.tb00215.x SZCZESNIAK, A. S. 1975. Textural characterization of temperature sensitive foods. Journal of Texture Studies, 6, 139-156. https://doi.org/10.1111/j.17454603.1975.tb01122.x

THYBO, A. K., MARTENS, M. 2000. Analysis of sensory assessors in texture profiling of potatoes by multivariate modelling. Food Quality and Preference, 11(4), 283-288. https://doi.org/10.1016/S0950-3293(99)00045-2

TRANCOSO-REYES, N., OCHOA-MARTÍNEZ, L. A., BELLO-PÉREZ, L. A., MORALES-CASTRO, J., ESTÉVEZ-SANTIAGO, R. OLMEDILLAALONSO, B. 2016. Effect of pre-treatment on physicochemical and structural properties, and the bio accessibility of $\beta$-carotene in sweetpotato flour. Food Chem, 200, 199-205. https://doi.org/10.1016/j.foodchem.2016.01.047

TRUONG, V. D., WALTER, W. M., 1994. Physical and sensory properties of Sweetpotato puree texturized with cellulose derivatives. Journal of food science, 59(6), 1175-1180. https://doi.org/10.1111/j.1365-2621.1994.tb14670.x
TRUONG, V. D., HANANN, D.D., WALTER, J. R. 1997. Relationship between instrumental and sensory parameters of cooked sweetpotato texture. $J$ Texture Stud, 28, 163-185. https://doi.org/10.1111/j.1745-4603.1997.tb00109.x

TRUONG, V. D., WALTER, W. M., BETT, K. L., 1998. Textural properties and sensory quality of processed sweetpotato as affected by low temperature blanching. Journal of Food Science, 63(4), 739-743. https://doi.org/10.1111/j.1365-2621.1998.tb15826.x

TRUONG, V. D., AVULA, R. Y., PECOTA, K., YENCHO, C. G. 2011 Sweetpotato. In: Handbook of Vegetables and Vegetable Processing, 717-737. https://doi.org/10.1002/9780470958346.ch36

VAN MARLE, J. T., DE VRIES, R. V. D. V., WILKINSON, E. C., YUKSEL, D. 1997. Sensory evaluation of the texture of steam-cooked table potatoes. Potato Research, 40, 79-90. https://doi.org/10.1007/BF02407564.

WALTER, W. M. 1987. Effect of curing on sensory properties and carbohydrate composition of baked sweetpotato. J Food Sci, 52, 1026-1029. https://doi.org/10.1111/j.1365-2621.1987.tb14267.x

WALTER, J. R. W. M., PALMA, C. S. 1996. Effect of Long-Term Storage on Cell Wall Neutral Sugars and Galacturonic Acid of Two Sweetpotato Cultivars. Journal of Agriculture and Food Chemistry, 44(1), 278-281 https://doi.org/10.1021/if950101u

WALTER, W. M., COLLINS, W. W., TRUONG, V. D., FINE, T. I. 1997. Physical, compositional, and sensory properties of French fry-type products from five sweetpotato selections. Journal of Agricultural and Food Chemistry, 45(2), 383-388. https://doi.org/10.1021/jf960061

WALTER, W., TROUNG, V., ESPINEL, K., 2002. Textural measurements and product quality of restructured sweetpotato French fries. LWT-Food Science and Technology, 35(3), 209-215. https://doi.org/10.1006/fstl.2001.0840

WOOLFE, J. A. 1992. Sweetpotato. An Untapped Food Resource, Cambridge, U. K: Cambridge University Press. ISBN-13: 978-0521050531. 